\title{
TINJAUAN YURIDIS TERHADAP TINDAK PIDANA PEMERKOSAAN YANG MENYEBABKAN KEMATIAN (STUDI) KASUS PENGADILAN NEGERI KENDAL
}

\author{
Pande Komang Satya Parama Hamsa, I Nyoman Gede Sugiartha, Ni Made Sukaryati Karma \\ Fakultas Hukum, Universitas Warmadewa, Denpasar-Bali, Indonesia \\ pandesatya5@gmail.com, nyomansugiartha14@gmail.com, madesukaryatikarma@gmail.com
}

\begin{abstract}
Abstrak
Pemerkosaan adalah sebuah criminal yang berat lantaran merugikan korbannya, Mengganggu masa depan, dan menyebabkan pengaruh yang sangat jelek bagi korban bahkan hingga terjadinya kematian. Tujuan dari penelitian ini adalah untuk mengungkap sanksi pidana terhadap tindak pidana pemerkosaan yang menyebabkan kematian serta pertimbangan hakim dalam menjatuhkan putusan tindak pidana pemerkosaan yang menyebabkan kematian. Metode yg digunakan dalam penelitian ini adalah penelitian normatif dengan pendekatan kasus dan perundang-undangan. Sumber bahan hukum yang digunakan berupa sumber hukum sekunder dan primer yang kemudian dianalisis secara deskriptif. Hasil penelitian mengungkapkan bahwa pelaku melanggar ketentuan pasal 285 , 288 ayat (3), 359, 291 ayat (2) kitab undang-undang hukum pidana, pasal 76D dan 81 ayat (1) Undang-undang Nomor 35 tahun 2014 atas perubahan Undang-undang Nomor 23 tahun 2002 mengenai Perlindungan Anak, dan melanggar ketentuan pasal 71 undang-undang No. 11 tahun 2012 mengenai Sistem Peradilan Pidana Anak. Hakim menghukum terdakwa dengan sanksi penjara selama 4 tahun.
\end{abstract}

Kata Kunci: Kematian, Pemerkosaan, Pidana, Studi Kasus

\begin{abstract}
Rape is a serious crime because it harms the victim, disturbs the future, and causes a very bad influence on the victim, even death. The purpose of this study is to reveal the criminal sanctions against the crime of rape that causes death and the judge's considerations in deciding the crime of rape that causes death. The method used in this research is normative research with a case and legislation approach. Sources of legal materials used in the form of secondary and primary legal sources which are then analyzed descriptively. The results of the study revealed that the perpetrator violated the provisions of Article 285, 288 paragraph (3), 359, 291 paragraph (2) of the Criminal Code, Article 76D and 81 paragraph (1) of Law Number 35 of 2014 on amendments to the Law. Number 23 of 2002 concerning Child Protection, and violates the provisions of Article 71 of Law no. 11 of 2012 concerning the Juvenile Criminal Justice System. The judge sentenced the defendant to 4 years in prison.
\end{abstract}

Keywords: Death, Rape, Criminal, Case Study

\section{PENDAHULUAN}

Indonesia merupakan negara Hukum yang menjamin pemenuhan hak dan keadilan rakyat bagi negaranya. Salah satu jenis dari hak tadi yaitu adalah Hak-Hak Asasi Manusia, dimana disebut HAM. HAM merupakan suatu hak dasar seseorang yang paling utama melekat di dalam badan seseorang semenjak seorang dilahirkan sebagai anugerah ciptaan Tuhan. Dewasa ini masalah-masalah aturan terkait HAM yaitu suatu masalah yang sering dibicarakan atau sering sebagai perhatian publik.

Peristiwa di dalam menegakan aturan hukum kepada tersangka pelecehan seksual yang mana tersangka menyebabkan terjadinya korban pelecehan seksual, dimana dalam kasus ini. selalu menjadi kasus yang sangat perlu untuk dicermati. Hukuman-hukuman bagi tersangka pelecehan seksual, dimana dalam kasus ini rasa keadilan bagi korban pelecehan seksual tidak memiliki rasa keadilan bagi korban pelecehan seksual, kerabat korban atau warga yang menaruh rasa kasihan kepada korban.

Peristiwa tindak pidana pelecehan seksual bagi tersangka akan diberikan sanksi yang tegas, yang rencananya diperberat hukuman kepada tersangka pelecehan seksual berupa sanksi mati, oleh karena itu perlu kita ketahui bersama sejauh mana korban dapat mendapatkan keadilan dari aturan hukum yang berlaku saat ini yang mana diperlukan baginya. Dalam hal ini perlindungan dan keadilan kepada korban pelecehan seksual sanggup disimpulkan sebagai keamanan dan keadilan 
baginya untuk mendapatkan agunan aturan hukum dari deritaan yang menimpanya serta depresi baginya yang menjadi korban pelecehan seksual (Arief, 2001).

Korban pelecehan seksual ialah mereka yang merasakan penderitaan jasmani dan rohani yang memberikan efek dari sebuah perilakunya sendiri maupun perilaku orang lain, semestinya keinginan mendapatkan rasa keadilan adalah sebuah kepentingan dirinya sendiri maupun orang lain yang bertentangan dengan penggunaan HAM yang dirugikan (Arif, 1993). Penerapan sanksi pidana terhadap pelaku kejahatan sudah merupakan cara terbaik untuk menegakan keadilan. Aparat penegak hukum harus lebih memperhatikan terhadap korban yang menjadi korban kejahatn yang tidak hanya dapat menimbulkan penderitaan fisik, tetapi juga mental dan psikis (Novitasari et al., 2020).

Dampak dari sebuah kejahatan menyebabkan korban/objek dan depresi. Depresi menjadikan seorang takut serta merasakan penderitaan terlebih sang korban sendiri, maupun sang pihak lain secara tidak langsung (Sahetapy, 1987). Menurut Kitab Undang-Undang Hukum Pidana, sebuah kejahatan dalam bentuk pelecehan seksual ini diatur dalam Pasal 285 kitab undang-undang hukum pidana. Pasal ini diatur dalam BUKU II BAB XIV Tentang Kejahatan Terhadap Kesusilaan.

Setiap seseorang yang melakukan sebuah kejahatan atau kriminal disamping terdapat pelaku serta menimbulkan atau menyebabkan adanya korban. Dimana korban timbul dari sebuah kejahatan pelecehan seksual ataupun saksi yang ikut serta melihat kejadiaan tersebut dilakukan tersangka dalam aksi kejahatan ialah korban ataupun saksi, saksi ialah yang mana ikut serta menyaksikan suatu aksi kejahatan dan dapat menolong, memastikan kepentingan dalam suatu kejahatan. Adanya kasus ini tentunya terjadi karena faktor internal dan eksternal, faktor internal ini meliputi faktor agama, pendidikan, pergaulan, lingkungan serta faktor ekonomi. Lalu faktor eksternal meliputi faktor korban, faktor ekonomi seta faktor penggunaan narkotika atau minuman keras (Nurdiana \& Arifin, 2019).

Ketika korban menjadi objek di dalam peristiwa berdasarkan tindak kejahatan yang dilakukan oleh tersangka. Korban ialah objek yang merasakan derita didalam suatu insiden kejadian tersebut. Dalam hal ini, Ketika objek pelecehan seksual yang merasakan penderitaan dari efek tindak kejahatan serta dialaminya. Maka diperlukannya untuk mengetahui rasa keadilan sampai sejauh manakah objek kejahatan dapat memperoleh keamanan aturan hukum yang berlaku sesuai yang diperlukan baginya. Pemerkosaan adalah bentuk kriminal yang sangat berat karena menimbulkan depresi objeknya, mengganggu perilakunya, serta menyebabkan dampak yang sangat-sangat tidak bagus bagi objek tindak kejahatan dimana hingga menyebabkan sampai terjadinya kematian. Biasanya kepada objek maupun kerabat objek tidak berani dan takut untuk melaporkan kepada pihak berwenang ataupun menceritakan kepada orang lain. Yang mana menjadi pokok konflik ini adalah sebuah kejahatan asusila dimana dilakukan oleh pelaku yang benama Nico yang masih berumur 16 tahun kepada objek yang bernama Ratih berumur 15 tahun. Dimana dilakukan pada hari minggu 10 September 2006 sekitar waktu 10.00 wib, melakukan tindak pidana pelecehan seksual yang mengakibatkan kematian. Kerabat korban melaporkan kejadian tersebut kepada kepolisian, lalu perkara tersebut ditangani oleh Pengadilan daerah Kendal dan sudah disidangkan dimana perkara tersebut akhirnya menetapkan menggunakan putusan hakim Nomor 187/pid.b/2006. Yang mana dalam putusan hakim tersebut yaitu memberikan sanksi kepada tersangka pelecehan seksual (terdakwa) berupa sanksi empat tahun penjara bagi tersangka, terkait dengan didasarkan dalam pasal 285, pasal 291 ayat (2) kitab undangundang hukum pidana dan Undang-undang Nomor 3 Tahun 1997.

Berdasarkan masalah perkara diatas korban pelecehan seksual telah kehilangan moralnya, hilangnya keperawan, dan sebagainya yang merugikan dirinya. Kejahatan pelecehan seksual dapat disimpulkan sebagai masalah criminal tertutup, sebuah kejahatan berupa pelecehan seksual yang dievaluasi bisa menurunkan moral seorang perempuan dan mengganggu harkat dan martabatnya. Bagaimanapun perempuan merupakan Ibu berdasarkan umat manusia, karena dari rahim dialah bayi atau kita dilahirkan.

Hakikat didalam sebuah kejahatan harusnya dipandang menjadi suatu yang sangat penting dikarenakan merugikan korbannya, karenanya sanksi yang diberikan kepada pelaku wajib juga memperhatikan kepentingan sang korbannya. di dalam pemulihan peristiwa yang diderita yang wajib dipulihkan yaitu tidak saja masalah fisik namun juga masalah non fisik.

Berdasarkan penelitian terdahulu, menurut (Setiawan, 2018) secara yuridis pengaturan mengenai kejahatan kekerasan seksual (perkosaan) diatur dalam ketentuan Pasal 285 KUHP yang memiliki unsur yang harus dipenuhi, salah satunya adalah adanya kekerasan. Lebih lanjut, (Barus, 
2020) mengungkapkan bahwa pertanggungjawaban pidana pelaku tindak pidana kekerasan yang menyebabkan korban meninggal dunia telah diatur dalam Pasal 170 ayat (2) ke 3 KUHP tentang tindak pidana secara terang-terangan dan dengan tenaga bersama melakukan kekerasan yang mengakibatkan matinya orang lain dan terpenuhinya unsur-unsur tersebut dan tidak ada alasan pembenar dan alasan pemaaf. Sudah seharusnya hukum pidana memberikan sanksi yang setimpal bagi pelaku kejahatan pemerkosaan sehingga supremasi hukum benar-benar ditegakkan dan tercipta ketertiban dalam masyarakat. Disamping itu, sanksi tersebut diharapkan memberikan efek jera bagi pelaku kejahatan sehingga tidak akan mengulangi perbuatannya dimasa mendatang serta mencegah orang lain agar tidak melakukan kejahatan tersebut karena suatu ancaman sanksi yang cukup berat (Purba \& Santoso, 2013).

Berdasarkan pemaparan diatas, maka didapat suatu tujuan penelitian yang pertama sanksi pidana terhadap tindak pidana pemerkosaan yang mengakibatkan kematian yang kedua pertimbangan hakim dalam menjatuhkan putusan tindak pidana pemerkosaan yang mengakibatkan kematian.

\section{METODE PENELITIAN}

Metode yang dipakai pada penelitian ini yaitu penelitian aturan normatif yaitu menggunakan melakukan pengkajiannya dari bahan-bahan aturan berdasarkan literatur dan ialah suatu proses dimana untuk menentukan aturan hukum, prinsip sebuah aturan, juga doktrin-doktrin aturan menjawab permasalahan sebuah aturan yang dihadapi demi membentuk argumentasi, teori dan konsep baru menjadi preskripsi pada menuntaskan kasus yang dihadapi. Sedangkan pendekatan kasus yang dipakai adalah pendekatan perundang-undangan dengan mengkaji seluruh Undang-Undang dan regulasi yang bersangkut paut menggunakan informasi aturan yang dihadapi. Adapun sumber bahan aturan yang dipakai basic primer dan sekunder yang dipakai yaitu misalnya UUD Negara Republik Indonesia Tahun 1945, Kitab Undang-Undang Hukum Pidana, Undang-Undang Nomor 36 Tahun 2009 mengenai Kesehatan, Undang-Undang Nomor. 35 Tahun 2014 Tentang Perubahan Atas UU. No. 23 Tahun 2002 Tentang Perlindungan Anak. Selain itu juga berpedoman dalam buku hukum, jurnal-jurnal aturan, surat kabar, dan pula berdasarkan internet yang berkaitan menggunakan Perlindungan Hukum terhadap tindak pidana pelecehan seksual yg mengakibatkan kematian menjadi konflik yang dibahas. Teknik pengumpulan bahan hukum dengan menganalisis peraturan perundangundangan, risalah resmi, dan beberapa keputusan-keputusan yang menyangkut dengan judul penelitian ini yang kemudian dianalisis secara deskripstif.

\section{HASIL DAN PEMBAHASAN}

\section{Sanksi Pidana Terhadap Tindak Pidana Pemerkosaan yang Menyebabkan Kematian}

Pengertian sanksi pidana dapat dibagi menjadi dua istilah, yaitu sanksi dan pidana. Sanksi adalah suatu tuntutan,berupa tuntutan pidana dan memiliki fungsi supaya kebiasaan yang sudah di tetapkan pada aturan dan peraturan-peraturan ditaati menjadi dampak aturan berdasarkan kebiasaan yang dilanggar (Poernomo, 1993). Hukuman dapat dimaksud menjadi dampak suatu kegiatan atau suatu timbul akibat menurut tentang hal lain dimana dilakukan oleh manusia atau kelompok sosial (Utrecht, 1960).

Pada dasarnya hukuman berfungsi untuk mengembalikan kestabilan kehidupan rakyat serta menghalangi bagi pelanggar kaidah pada keadaan semulanya. Pidana ddalam tujuannya ialah suatu pengenaan peristiwa atau derita ataupun dampak-dampak lain yang sangat tidak menyenangkan. Sebuah hukuman diberikan dengan sengaja kepada seorang atau organisasi. Hukuman diberikan kepada seorang ketika melakukan tindak pidana berdasarkan perundang-undang.

Suatu wilayah didalam melaksanakan hukuman pidana dapat mengklaim kemerdekaan tersendiri dan melindungi agar eksklusif rakyat tetap dihargai. Sedangkan karena itu, pemidanaan wajib memiliki arah dan fungsi dimana bisa menjaga kesetabilan tersendiri menggunakan keinginan rakyat dalam menuju kemakmuran bersama.

Pengertian perkosaan dapat diartikan yaitu perkosa dimana memiliki arti paksa, kuat, gagah, perkasa, sadis. Memperkosa ialah kejadian dimana menggunakan paksaan, rayuan, dan menggunakan kekerasan. melainkan perbuatan pelecehan seksual diartikan menjadi proses suatu perbuatan memperkosa menggunakan kekerasan. Jika demikian di dalam kamus besar bahasa indonesia perkosaan mempunyai unsur sebagai berikut yaitu laki-laki memaksa menggunakan kesadisan, bersetubuh menggunakan seseorang perempuan. 
Sanksi pidana terhadap pelaku pelecehan seksual yang mengakibatkan kematian dapat menaruh efek jera bagi pelaku. Adapun jenis-jenis tindak pidana bisa dikategorikan berdasarkan pasal 10 kitab undang-undang hukum pidana yaitu pidana pokok dan pidana tambahan. Dengan demikian, inti berdasarkan konflik ini bahwa pelaku melanggar ketentuan pasal 285, pasal 288 ayat (3) pasal 359 dan pasal 291 ayat (2) kitab undang-undang hukum pidana, pasal 76D dan 81 ayat (1) undang-undang nomor 35 tahun 2014 atas perubahan undang-undang nomor 23 tahun 2002 mengenai perlindungan anak, dan melanggar ketentuan pasal 71 undang-undang no. 11 tahun 2012 mengenai sistem peradilan pidana anak.

\section{Pertimbangan Hakim Dalam Menjatuhkan Putusan Tindak Pidana Pemerkosaan yang Menyebabkan Kematian}

Pengertian putusan ialah merupakan arti dari nilai-nilai kebenaran, keadilan, HAM kewenangan aturan ataupun berita secara nyata, dan faktual, dan visualisasi etika, moralitas dan mentalitas berdasarkan dimana hakim ikut dalam kegiatan tersebut. Sebuah putusan ketika menyatakan pelepasan terdakwa, maka terdakwa yang berada pada status tahanan diperintahkan untuk dilepaskan ketika pada saat itu, misalkan lantaran terdapat tumpuan yang absah, terdakwa tetap ditahan, contohnya terdakwa ikut serta didalam kasus lainnya, baik dalam diri dia juga bersama-sama dengan sekelompoknya. Dimana dalam putusan berbentuk putusan lepas menurut berbagai petisi aturan merupakan putusan dapat dijatuhkan pada terdakwa ketika sehabis terjadinya pemeriksaan, ternyata berdasarkan argumen dari hakim, ketika perbuatan didakwakan kepada terdakwa serta terbukti bersalah, namun perbuatan tersebut tidak dapat dikatakan suatu tindak pidana.

Putusan berupa pemidanaan merupakan putusan yang memberatkan suatu kejahatan pada terdakwa lantaran perbuatan yang didakwakan memiliki bukti secara absah dan meyakinkan kepada terdakwa benar-benar bersalah serta melawan hukum terkait dilakukannya. Dimana dalam hal ini, sesudah pelimpahan kasus dan jika terdakwa serta pengacaranya mengajukan eksepsi atau ketidakpuasan terhadap surat dakwaan jaksa atau penuntut umum. Serta hakim menyetujui atau mendapat eksepsi, maka berakhirlah kasus itu. Bagaimana ketika putusan mengenai eksepsi itu penuntut umum bisa mengajukan perlawanan pada pengadilan tinggi melalui pengadilan negeri yang bersangkutan. Jadi Jika hakim berpendapat terhadap eksepsi tersebut tidak bisa diterima atau baru bisa diputus sehabis terselesainya pemeriksaan, maka sidang dilanjutkan. Terhadap putusan (sela) itu bisa diajukan perlawanan bersama- sama menggunakan permohonan banding.

Pada hakikatnya didalam putusan yang mana bukan merupakan putusan akhir dapat berupa yaitu:

a) Memiliki sifat penetapan serta tidak menjatuhkan pidana, melainkan berupa tindakan hakim, misalkan yaitu memasukkan ke rumah sakit jiwa, menyerahkan ke lembaga pendidikan khusus anak nakal, dan lain-lain.

b) Memiliki sifat penetapan serta tidak berwenang dalam mengadili perkara terdakwa, misalkan yaitu terdakwa menjadi kewenangan untuk diadili oleh mahkamah militer.

c) Memiliki sifat penetapan serta pernyataan surat-surat tuduhan batal dikarena tidak mengandung isi yang diharuskan oleh syarat formal undang- undang, misalkan yaitu surat tuduhan tidak terang mengenai waktu dan tempat perbuatan dilakukan.

d) Memiliki sifat penetapan serta menolak ataupun tidak menerima tuntutan yang diajukan oleh penuntut umum, misalkan yaitu perkara jelas delik aduan tidak disertai surat pengaduan atau tidak diadukan oleh si korban ataupun kerabatanya.

Selanjutnya, majelis hakim pengadilan negeri kendal terlebih dahulu membandingkan apa yang akan menjadi dasar factor/alasan yang sebagai dasar pertimbangan majelis hakim didalam menjatuhakn pidana kepada pelaku pelecehan seksual hingga mengakibatkan kematian.

Berdasarkan uraian diatas, hakim mempunyai pertimbangan-pertimbangan sendiri dalam menjatuhkan pidana terhadap terdakwa tindak pidana pelecehan seksual yang mengakibatkan kematian. Majelis Hakim menjatuhkan putusannya, mengatakan terdakwa Nico sudah benar-benar terbukti secara abash serta meyakinkan benar-benar bersalah melakukan perbuatan tindak pidana pemerkosaan sampai mengakibatkan orang meninggal. Menghukum serta memenjarakan terdakwa Nico berupa hukuman pidana penjara selama 4 (empat) tahun. Hakim menyatakan yaitu kepada terdakwa Nico benar-benar melakukan perbuatannya serta terbukti melakukan dan keyakinannya mengenai kesalahan diperbuatnya yaitu melakukan pemerkosaan sampai mengakibatkan korban meninggal dan dalam hal ini bahwa terdakwa didakwa oleh hakim pengadilan negeri kendal yaitu Melanggar pasal 285 kitab 
undang-undang hukum pidana jo 291 ayat (2) kitab undang-undang hukum pidana jo undang-undang nomor 3 tahun 1997 mengenai pengadilan anak, melanggar pasal 81 undang-undang republik Indonesia nomor 23 tahun 2002 mengenai perlindungan anak, melanggar pasal 359 kitab undangundang hukum pidana dan melanggar peraturan perundang-undangan yang bersangkutan. Dalam hal ini, Majelis Hakim yang bertempat di kabupaten Kendal sudah melakukan perbandingan dalam memberikan alasan/factor yang mana sebagai dasar pertimbangan hakim dalam menjatuhkan pidana terhadap tersangka tindak pidana berupa pelecehan seksual yang mengakibatkan kematian. Ada beberapa alasan serta sebagai perbandingan majelis hakim dalam memberikan putusan kepadanya, yaitu

Faktor serta alasan yang dapat memberatkannya

1. Tingkah laku pelaku sudah menurunkan moral dan pribadi seseorang perempuan yang masih muda.

2. Tingkah laku pelaku sudah mengkhawatirkan rakyat.

3. Tingkah laku pelaku membuat perbuatan asusila. Hal yang dapat memberikan keringanan yaitu pelaku sudah meratapi kelakuannya, Pelaku merupakan seorang anak muda dan masih menginginkan serta melanjutkan sekolahnya, Pelaku berjanji tak akan mengulangi perbuatan asusila lagi.

Majelis hakim menetapkan serta menjatuhkan sanksi penjara selama 4 tahun lantaran didasarkan beberapa pertimbangan, diantaranya

1. Pelaku masih muda dan masih ingin melanjutkan sekolahnya.

2. Selama dalam persidangan pelaku bersikap baik, sopan dan mengakui setiap kelakuannya.

3. Pelaku merasa sangat menyesal atas kelakuannya dan tak akan melakukannya lagi.

Berdasarkan alasan-alasan dan pertimbangan tersebutlah, maka majelis hakim menghukum terdakwa menggunakan sanksi penjara selama 4 tahun. Sesuai ketentuan pasal 285 No pasal 291 ayat (2) kitab undang-undang hukum pidana No. pasal 23 UU no.3 tahun 1997. Yang mana memiliki unsur sebagai berikut, yaitu

1. Unsur barang siapa

2. Dengan kekerasan atau ancaman kekerasan

3. Memaksakan wanita yang bukan istrinya bersetubuh dengan dia

4. Sehingga mengakibatkan korban meninggal

\section{SIMPULAN DAN SARAN}

\section{Simpulan}

Sanksi pidana terhadap tindak pidana pemerkosaan yang mengakibatkan kematian. Bahwa pelaku melanggar ketentuan pasal 285 kitab undang- undang hukum pidana, pasal 288 ayat (3) pasal 359 dan pasal 291 ayat (2) kitab undang-undang hukum pidana, pasal 76D dan 81 ayat (1) Undang- undang Republik Indonesia Nomor 35 tahun 2014 atas perubahan Undang- undang Nomor 23 tahun 2002 mengenai Perlindungan Anak, dan melanggar ketentuan pasal 71 undang-undang No. 11 tahun 2012 mengenai Sistem Peradilan Pidana Anak. Sedangkan pertimbangan hakim pada menjatuhkan putusan berupa tindak pidana pemerkosaan yang mengakibatkan kematian, pada putusan Pengadilan Negeri Kendal No.187/ Pid/b/2006/Pn.Kdl mengenai Tindak Pidana Pemerkosaan Yang Menyebabkan Kematian. Berdasarkan alasan-alasan dan pertimbangan-pertimbangan maka majelis hakim menghukum terdakwa dengan sanksi penjara selama 4 tahun. Sesuai melanggar pasal 285 kitab undang-undang hukum pidana No. Pasal 291 ayat (2) kitab undang- undang hukum pidana No. pasal 23 UU No.tiga tahun 1997 yang mana memiliki unsur-unsur yaitu sebagai berikut unsur barang siapa, menggunakan kekerasan atau ancaman kekerasan, memaksakan wanita yang tidak istrinya bersetubuh menggunakan dia, sampai mengakibatkan korban meninggal.

\section{Saran}

Bagi aparat penegak hukum terutama hakim pada menangani suatu perkara wajib bersifat objektif pada artian majelis hakim wajib memberikan hukuman yang sesuai menggunakan peraturan perundang-undangan yang berlaku di Indonesia, dan bisa mempertimbangkan keterangan-keterangan yang dihadapkan pada persidangan, sebagai akibatnya pada hukuman yang diberikan bisa memuat nilai-nilai keadilan, kepastian, dan kemanfaatan aturan. Sedangkan untuk anak dibawah umur 
dibutuhkan bisa menentukan pergaulan yang lebih baik, lantaran pergaulan di sekitar lingkungan sangat gampang menjerumuskan dalam perilaku yang menyimpang. Oleh karenanya dibutuhkan orang tua dapat juga mengontrol dan bisa menaruh pengawasan pada seseorang anak dalam menentukan pergaulan sehari-hari. Sehingga bisa mencegah terjadinya hal-hal yg tidak diinginkan atau menyimpang tingkah laku anak dan kenakaln remaja yang bisa menyebabkan kejahatan. lantaran orang tua sangat penting berperan dalam membentuk karakter dan kepribadian yang baik melalui pengajaran.

\section{DAFTAR PUSTAKA}

Arief, B. N. (2001). Masalah Penegakan Hukum dan Kebijakan Penanggulangan Kejahatan. P.T. Citra Aditya Bakti, Bandung.

Arif, G. (1993). Masalah Korban Kejahatan. Akademika Prassindo, Jakarta.

Barus, G. R. (2020). Analisis Hukum Pidana Terhadap Tindak Pidana Kekerasan yang Mengakibatkan Korban Meninggal Dunia. Jurnal Hukum Dan Kemasyarakatan, 1(1), 79-93.

Novitasari, K. D., Widiati, I. A. P., \& Laba, I. N. (2020). Tinjauan Yuridis Terhadap Tindak Pidana Perkosaan Dalam Perspektif Hak Asasi Manusia. Jurnal Analogi Hukum, 2(3), 388-392.

Nurdiana, M. A., \& Arifin, R. (2019). Tindak Pidana Pemerkosaan: Realitas Kasus dan Penegakan Hukumnya di Indonesia. Jurnal Untidar, 3(1), 52-63.

Poernomo, B. (1993). Asas-Asas Hukum Pidana. Ghalia Indonesia, Jakarta.

Purba, E. P., \& Santoso, O. B. (2013). Kajian Hukum Pidana Terhadap Tindak Pidana Pembunuhan Terencana disertai Pemerkosaan Sebagai Concursus Realis. Recidive, 2(1), 22-28.

Sahetapy, J. E. (1987). Viktimologi Sebuah Bunga Rampai. Pustaka Sinar Harapan, Jakarta.

Setiawan, I. (2018). Tindak Pidana Perkosaan Dalam Tinjauan Hukum Pidana Indonesia. Jurnal Ilmiah Galuh Justisi, 6(2), 125-137.

Utrecht, E. (1960). Hukum Pidana I. Pt Penerbitan Universal, Bandung. 